\title{
The Connection between Individual Characteristics of Small Enterprise Leader and the Use of Performance Measurement Systems (PMS): A Gabonese Case
}

\author{
Assey Mbang Janvier-James \\ Glorious Sun School of Business and Management, Donghua University \\ PO box 200051, Shanghai, China \\ E-mail: asseyjanvier@hotmail.com
}

Received: January 10, 2011 Accepted: March 11, $2011 \quad$ doi:10.5539/ijbm.v6n7p105

\begin{abstract}
We theorize about Enterprises Performance Measurement systems. 2001 Gabonese Small Enterprises were surveyed for the analysis. The first aim of this research is to examine how the enterprise leader's individual characteristics can impact on Performance Measure Systems. The second aim is to identify the relationship between performance measure systems and the enterprise management performance. The results of this research highlight that in the Gabonese context there is a significant connection between self-esteem, locus control and Performance measure systems. This paper also demonstrates that there is a relationship between Performance Measure Systems and Enterprise Management Performance.
\end{abstract}

Keywords: Small enterprises, Gabon performance Measurement systems, Enterprise performance, Self-esteem, Locus control, Intolerance, Ambiguity, Leader's individual characteristics

\section{Introduction and Research problematic}

Small Enterprises (SEs) play an important role in Gabonese economic development. Among the benefits of SEs, are the stabilization of the economy and the creation of employment. Study conducted by Franklin Assoumou Ndong (2003) and the Fund for the development and the expansion of SMEs in GABON (FODEX,2009) indicates that until 2008, there were 6000 private sector Small Enterprises representing 78\% of all Gabonese enterprises. In term of employment, the Small Enterprises employ 35.5\% of the Gabonese labor (Ministry of Economy and Finance of GABON, IMF, 2002). This demonstrates that the vitality of the Gabonese economy also depends on Small Enterprises incentive.

Therefore, since many Small Enterprises lack knowledge about designing and using performance measures in SEs, it becomes critical to question how SEs design and for which purpose they use them also, the impact of the design and the use of PMS on enterprise management performance, the impact of SEs leader's individual characteristics on the choice of PMS and their using. How can the enterprise leader's individual characteristics impact on PMS? What are the relationship between performance measurement systems and the enterprise management performance? Those questions constitute the purpose of this paper.

\section{Literature Review}

\subsection{The situation of Gabonese Small Enterprises}

Small Enterprises form the majority of private sector companies in GABON. They employ $35.5 \%$ of the GABON's labor (Ministry of Economy and Finance of GABON, IMF, 2002). The survey conducted in 2001 by the United Nations on employment in GABON, confirms this trend: $35 \%$ of Gabonese's labor work in Small Enterprises employing fewer than 60 employees and the remaining 65\% work in medium-sized enterprises and in the public institution (United Nations, 2001).

The Republic of GABON, which has a GDP of USD 3,860 per capita, is classed in the category of middle-income economies. This per capita income level is due mainly to the country's raw material exportation revenues. These raw materials attract important FDI. Although it's high level of per capita income, the country's economy levels remain low. "Standard \& Poor's and Fitch Ratings" rated GABON Bond ratings Below (M. Willy ONTSIA, 2007). In 2009, the Human Development Index ranked GABON 103rd out of 182 countries (ADB, GABON, Study on the Diversification of Sources of Economic Growth, ADB/BD/IF/2009/57, 2009). The country's Growth and Poverty Reduction Strategy Paper (GPRSP) found the private sector as the engine and the way of diversify economic growth, especially by promoting the development of SEs (Republic of GABON, Growth and Poverty Reduction Strategy Paper, 2006).

In the survey conducted by Panapress-GABON and published in February 2008, 52\% of Gabonese Small Enterprises leaders have indicated that freelance work is the most rewarding career (Panapress, 2008). 


\subsection{Gabonese Small Enterprises business management}

The study conducted by the OECD in 2005 highlights that operation of Gabonese SEs is closely packed by the management style of its main executive.

This view points is confirmed by several authors (Lynch, R \& Cross, K., 1991; Bescos P.L. et Cauvin E., 2004; Marchesnay \& Julien, 1996; Lipe. G.M et Salterio S.E, 2000; Levy \& Powell, 1998; Robson, Ian, 2005) who agree that the operation of SEs is closely packed by the management style of its principal executive officer or management team. For Tangen, Stefan (2004), the management control systems, in Gabonese Small Enterprises context, consist of a set of procedures and tools usually built into the system information officer of the enterprise and often used informally by an enterprise executive who is both the designer and facilitator analyst. Its point of view reinforces Denton, D. Keith (1995)'s view point. Dupuy (1987) observed that some leaders of small businesses manage successfully without some other information that accounting data basis. Moreover, Riggs \& Bracker (1986) show that U.S. Small Enterprises which implement the forecasting activities (including sales) and integrated planning generate higher financial performance. Overall findings indicate that management controls are much more sophisticated if SEs are larger than average, have a shareholding consisting of internal and external shareholders and have accountants who hold a university degree.

\subsection{The importance of Performance Measure Systems in Gabonese Small Enterprises}

Small Enterprises predominate in the Gabonese economic sector. These units provide employment for a significant portion of the population, but their contribution to the economy remains weak (Amadou BA, 2009).

According to Ducheneaut (1995), Wisner, J.D., and S.E. Fawcett (1991), Small Enterprise (SE) is an elusive concept because there is no universal definition of it. They have different definitions in developed countries than developing countries. Therefore SE poses a small problem with its definition and identification. For example, a Small Enterprise can employ more labor in one country and employ less in another country.

Other criteria may be taken into account to refine the definition. This is mainly the type of property and the degree of independence. SEs considered as companies that are independent in relation to groups or large companies that are in most cases run in families. We can use two criteria to define SEs. The first concerns the size. The second criterion concerns the degree of independence (Doha Abdelhamid \& Alia El Mahdi, 2003). Some data show an increase in the number of these SEs in GABON and other developing countries. Management tools will enable SEs survival and sustainability and contribute to their development. In this context we must seek to understand how SEs can improve their chances of survival and development through the use of management tools. Performance measurement systems can help to provide solutions for corporate performance (Mostafa Abakouy, 2006).

\subsection{Gabonese Small Enterprises and Performance Measures}

The literature proposes different theories and different tools for enterprise management, for example the configuration and the use of performance measures. It is certainly possible to apply some performance measures developed for large enterprises on SEs. However, we should not consider SEs as "small" large enterprises (Grepme, 1997).A different management approach is therefore required (Boyd, Lynn H., and James F. Cox, 1997) because SMEs face particular situations that not necessarily occur in large enterprises. SEs, therefore, won't necessarily use performance measures in the same purpose and in the same way as large enterprises. For example, the composition of the management team will be sometimes limited and by extension, the omnipresence of the leader is a factor that greatly influences the management of SEs (Julien P-A; Marchesnay M.,1988).

Researches on the configuration and the use of performance measures are growing in management accounting literature (Kaplan, R.S. \& Norton, D.P., 1992; Hudson, M. Smart, A. \& Bourne, M., 2001; Fitzgerald, L. Johnson, R., Brignall, S.,et al.,2002; Bititci, U.,1994.; Gerdin, J., \& Grève, J.,2007; Chow, C, W. Haddad, K.M. \& Williamson, J.E.,1997).

These studies were conducted by analyzing majority of large enterprises. In addition, various studies have been conducted mainly at an organizational level, especially by discussing about the organizational performance of enterprises. Until nowadays, few studies have tested the relationship between the individual characteristic's characteristics of enterprises leader and the performance measures, in a contingency perspective (Chong, 1998).

In conclusion, considering the importance of SEs in Gabonese economic activity, the specific characteristics of Gabonese SEs and the undeveloped knowledge about the configuration and the use of performance measures in SEs, it becomes relevant to conduct a study about Gabonese Small Enterprises and Performance Measures Systems

\subsection{Individual characteristics of Small Enterprises Leaders}

In this section we will analyze the main individual characteristics of SEs leaders that have been measured by several researchers. The main individual characteristics tested are:

\subsubsection{Preference for Innovation}


Germain C. (2004) defines innovation in terms introduction of new products, new production methods, opening new markets or new sources of supply and the reorganization of the business, market and industry.

\subsubsection{Rigidity}

Kalika M. (1987) defines the rigidity as a lack of adaptability and variability. Kounin (1948) extends the definition of rigidity as the degree of differentiation of individuals. An individual whose individual characteristics are relatively undifferentiated tends to be more rigid due to stereotyped behaviors learned and little opportunity to take action. Rokeach (1960) combines rigidity with resistance to change.

2.5.3 Need for achievement, power and affiliation

Mc Clelland (1961) identifies three needs from an individual for his motivation: achievement, power and affiliation. The need for achievement is linked to individual desires to be fulfilled, of master a skill, control and establish high standards. The power one is divided into two parts, social power and personal power, the power is the ability to influence its environment through its commitment. The affiliation need is defined as the need to belong to a group, to establish harmonious relations with its environment and the need to feel accepted by others.

2.5.4 Intolerance of ambiguity

Budner (1962) defines the ambiguity as the lack of sufficient evidence to properly structure a situation. The ambiguity may come from the novelty, complexity, or insolubility. Budner defines Intolerance for ambiguity as the tendency to perceive ambiguous situations as a threat while the tolerance for ambiguity is the result of collecting these situations as desirable.

\subsubsection{Locus control}

Rotter (1966) defines locus control as the ability of individuals to perceive the influence of events in his life. Individuals internal believe in their own ability to influence their lives and their behaviors give little attention to external events while those outside reject the rule that personal efforts are the primary determinant of their results.

\subsubsection{Tendency to take risks}

Brockhaus (1980) defines the tendency to take risks as the perception of the probability of receiving rewards associated with success in the situation given by the individual and the consequences associated with the failure of this situation, comparatively to a situation that would cause less rewards and less impact than the proposed situation.

\subsection{Performance Measure Systems}

For enterprises, a measure of performance can be financial or non-financial. The financial measures are used for a very long time. However, the literature criticizes this kind of measure of performance because it is often outdated (Fisher, 1992; Ittner \& Larcker,1998a).The non-financial measures are then emerged as an alternative, these measures are however not free from critical, because non-financial measures as far as financials are lead to dysfunctional behaviors that employees are acting in their own interests rather than the interests of the company (Fisher, 1992; Ittner \& Larcker, 1998a).The design of a performance measure help to assist leaders to make progress necessary to achieve goals and objectives desired by the company. (Chenhall, 2003).According to Malina \& Selto (2004), the design is the most important step of implementing a performance measure because the use is fairly simple when the right measures have been designed. Malina \& Selto continue in identifying characteristics of a good performance measure. These should be diverse and complementary, objective and verifiable, informative, a communication tool for the strategy, a tool to reward, and be useful for decision-making. Regarding the use of performance measures, they help to track results, directing attention to assist in decision-making (Simon \& al. 1954; Burchell et al.1980) provide a new possible use of performance measures in the case of the legitimization. Simon (1990) established two possible uses of performance measures; it develops the theory of using "diagnostic" and "interactive "of performance measures. The use of diagnostic is widely used and serves to coordinate and communicate the priorities of the organization, all associated with a reward system that focuses on cooperation of managers towards the priorities the organization. Grau, Micah E. (2008) studied the relationship between performance measures and approach based on resources. He concludes that the use of interactive performance measures has a positive influence on the capacity market orientation, entrepreneurship, innovation and learning organizational diagnosis and the use has the opposite effect.

This view point is confirmed by Naranjo-Gil \& Hartmann (2006); they indicated that the introduction of cost strategy is positively related to the use of diagnostic performance measure while the flexibility of the implementation of the strategy is positively affected by the interactive use of performance measures combined with the use of non-financial allocation resources. Finally Ittner et.al (2003) measured the implications for performance relating to the use of performance measures. They conclude that an organization which uses more comprehensive non-financial performance measures will experience higher return on investment. 


\subsection{Connection between individual characteristics, performance measure systems and enterprise management performance}

2.7.1 Intolerance for ambiguity, the diversity and the use of performance measures

According to Begley \& Boyd (1987), a leader who shows a greater intolerance for ambiguity would like to get more information than a leader with less intolerance for ambiguity to properly structured situations in order to improve enterprise performance but also its own performance. The leader will therefore use a greater variety of information, including performance measures (McGhee et al., 1978). To reduce the threat caused by the complexity of a situation (Budner, 1962), the leader wants to use all of these measures to ensure that the situation isn't out of control for him and the threat of uncertainty and lack of sufficient evidence to control the situation. This begs the following assumptions:

$\mathrm{H}_{1}$-The level of intolerance for ambiguity is positively associated with the diversity of performance measures

$\mathrm{H}_{2}$-When a leader shows a higher degree of intolerance ambiguity, the effect of performance measures diversity on enterprises management performance is higher.

The uncertainty created by the gap between information desired and information obtained (Galbraith, 1973) will ensure that the leader wants to use intensively performance measures not only for monitoring results, but also to direct attention, because in this case, the system put in place may be seen as an opportunity for learning and understanding the situation development (Chapman, 1997).

This begs the following assumptions:

$\mathrm{H}_{3}$-The level of intolerance for ambiguity is positively associated with the use of performance measures.

$\mathrm{H}_{4}$-When a leader demonstrates a higher degree of intolerance ambiguity, the effect of the use of performance measures on enterprise management performance is higher.

2.7.2 Locus control and the diversity of performance measures and Locus control and the use of performance measures

An internal locus control is a processor that is not enough efficient to help a leader to perform well. The leader would like to get additional information that are linked to results (Fisher, 1996). The leader with an internal locus control is able to know if the information is relevant or not, especially in situations of uncertainty. In situations where uncertainty is high, the leader will perceive the diversity of performance measures as more useful and relevant (Fisher, 1996). Leader with an internal locus control wants to use more different performance measures than a leader with an external locus control. This begs the following assumptions:

$\mathrm{H}_{5}$-An internal locus control is positively associated with performance measures' diversity.

$\mathrm{H}_{6}$-When a leader demonstrates an internal locus control, the effect of diversity of performance measures on enterprise management performance is higher.

The leader with internal locus control will tend to use performance measures more intensively. He would like to do more than simply measure results. He will be also more receptive to all performance measures but a leader with external locus control will not see the usefulness of performance measures.

The leader with an internal locus control will not only measuring results but also directs the attention of his employees to increase its own performance and the enterprise performance company.

We believe that the discussion takes the following assumptions:

$\mathrm{H}_{7}$-An internal locus control is positively associated with the use of performance measures.

$\mathrm{H}_{8}$-When a leader shows an internal locus control, the effect of the use of performance measures on enterprise management performance is higher.

2.7.3 Self-esteem and the diversity of performance measures and Self-esteem and the use of performance measures

Finally, the leader with lower self-esteem wants positive and regular confirmations to improve its performance. He will therefore likely to use more diversified performance measures in order to maintain its ability to reinforce in desirable situations. This begs the following assumptions:

$\mathrm{H}_{9}$-A low self-esteem is positively associated with the diversity performance measures.

$\mathrm{H}_{10}$-When a leader shows a low degree of self-esteem, the effect the diversity of performance measures on enterprise management performance is higher. In their study, Gregory B.Northcraft and Susan J. Ashford (1990) tested two types of feedback on individual characteristics, neutral feedback and reinforcement feedback. The neutral feedback consists simply to transmit results to the person without further comment. We can associate this type of feedback monitoring to the use of results while the use of reinforcement is used to communicate to the person the commented results that will support the assessment. We associate this kind of feedback to the use of performance measures in order to direct attention. 
The leader who shows a low self-esteem should also use performance measures to direct the attention. The leader showing a high degree of self-esteem, only use PMS for monitoring results is necessary because he believes in its capacity as leader and doesn't believe that he needs to direct attention to achieve his objectives.

This discussion begs the following assumptions:

$\mathrm{H}_{11}$-A low self-esteem is positively associated with the use of performance measures.

$\mathrm{H}_{12}$-When a leader demonstrates a degree of low self-esteem, the effect of the use of performance measures on enterprise management performance is higher.

\subsection{Relationship between performance measurement systems and enterprise management performance}

Performance measures systems are important for increasing enterprises performance (Epstein \& Manzoni, 1998 Said et al 2003.; Atkinson \& Epstein, 2000; Widener, 2007). Indeed, various authors studied the impact of performance measures on enterprises performance and demonstrate the positive impact of these various measures. (Epstein \& Manzoni1998, Said et al 2005; Atkinson \& Epstein, 2000; Widener, 2007) Investigations confirm a connection between performance measures and enterprise performance. Widener (2007), in his study, indicates that the performance measures act as a mediating agent between strategic resources and organizational performance. The results obtained in this research demonstrate that the belief systems of the enterprise influence and complete each other control systems, this in order to increase organizational performance.

What is consistent with results from Widener (2007) is: given that the manager is the leader of the enterprise, all the control systems and belief systems of the enterprise will be tinged with his individual characteristics, because all future decisions for the company will be influenced by its experiences, his will and his academic training. Other researchers have studied the enterprise management performance. Chong (1998) examined the moderating effect that can have the individual characteristics of the leader, the link between the configuration of performance measures and enterprise management performance. He concludes that alignment between individual characteristics and greater use of performance measures increases enterprise management performance.

Webb (2004)'s research discusses the importance of leaders engagement for performance measures systems to be effective. Webb (2004) also discussed the importance of establishing a causal link between performance measures and performance of the enterprise and that when leaders see the causal link, they will tend to adhere to new performance measures.

Hall (2008) also indicates that performance measures can have an effect on enterprise management performance in clarifying the expectations from the manager and clarifying its role and providing feedback to improve the intrinsic motivation of the manager. In the context of a Small Enterprise, a leader who will get the desired results with performance measures will tend to continue to improve behavior as personal and organizational to maintain the performance of the enterprise.

The use of performance measures examined in this study are those of performance monitoring and management of attention, which may be the reflect that the leader wants but cannot regularly follow (Monitoring) and he needs to validate regularly.

All these studies will allow us to conclude that performance measures are seen as increasing organizational performance, the performance measures chosen are such to attract the attention of employees on what is measured, resulting in a change in their

behavior and in the case of SEs, organizational performance is lead by the performance of the leader. These results lead to the following assumptions:

$\mathrm{H}_{13}$-The diversity of performance measures is positively associated with enterprise management performance.

$\mathrm{H}_{14}$-The use of performance measures is positively associated with enterprise management performance.

\section{Methodology}

\subsection{Sampling and Data Collection}

The population of this paper was constructed using the database "Répertoire des Petites et Moyennes Entreprises Gabonaises: Annuaire: Ministère des Petites et Moyennes Entreprises du GABON, 2010".

We identified a sample of 3000 Gabonese Small Enterprises, chosen randomly, but only 2001 showed interest in the research.

To be part of the sample, enterprises had to match the definition of SEs: (1) be a Gabonese enterprises; (2) employ fewer than 60 persons. The enterprise also must be a manufacturing company registered in the ministry of Small and Medium enterprises of Gabon.

It was also necessary that enterprises provide a valid address and the name of the leader as contact in the database. Only small enterprises have been selectioned.

Our survey was conducted in two stages: (1) first questionnaire mailing, (2) followed with $50 \%$ of enterprises that did not respond to the first mailing. The mailing consisted of sending a cover letter, a questionnaire and 
return "prepaid freight" envelope by post (1700 enterprises) or by email (301enterprises). The surveys were conducted at an interval of five weeks between the first and second mailing. Among the " 237 questionnaires" for this survey, "116" were received after the first mailing, "121" were received after the second mailing (see the table 1).

It is important to note that the "237 questionnaires" received give a response rate of $11,84 \%$, by taking into account the number of questionnaire sent minus the questionnaires returned for various reasons :enterprise closed, wrong addresses. This rate of answer, although not very high, was already recognized as significant by Widener (2007) on his study about the levers of control. It is also important to consider the fact that the rate of answer is calculated on a sample of 2001 enterprises.

\subsection{Nonresponse bias analysis}

In order to validate the nonresponse bias, we compared available data in the "Repertoire des Petites et Moyennes Entreprises Gabonaises: Annuaire: Ministère des Petites et Moyennes Entreprises du GABON, 2010" database for respondents and non-respondents of the survey in respect to age and size of enterprises. Using the T-test, we found no significant difference to a threshold of 0.05 between the averages of two groups ( 0 being the group which did not respond and 1 being the group that responded to the survey). The test results are presented in Table 2 and Table 3.In regard to the different industries represented in the sample; we can say that there is no non response bias. Indeed, the test performed (chi-square) is not significant at a threshold of 0.05 as shown in Table 4 .

\subsection{Descriptive statistics of respondents}

The enterprise size of respondents was calculated according to the number of enterprises employees. Respondents employ between 1 and 348 employees. (Table 5a).The experience of respondents in their current position ranged from 1 year to 66 years old. The frequency distributions of years of experience are presented in Table 5b. Over 30 percent of enterprises which responded are family businesses (Table 5c). Respondents have turnovers ranging from $\$ 80.000$ to 30 million (Table 5d).Enterprises ages are ranging from 2 to 80 years (Table $5 \mathrm{e})$.

Regarding the specialization of respondents, $31.13 \%$ are specialized in business administration; while $62.87 \%$ are specialized in sales and marketing (Table 5f.).Regarding the education background, $53.60 \% \%$ of respondents hold high a school degree, and $46.41 \%$ obtained a university degree (Table 6g.).Respondents come from two principal cities of GABON: Libreville (60\%) and Port-Gentil $(40 \%)$. (Table 5h.). The sector in which respondents operate is presented in table $5 \mathrm{i}$.

\subsection{Measuring constructs}

The different constructs were measured using a questionnaire. The first section of the questionnaire evaluates the individual characteristics of SEs leaders using statements from different tests. The leaders were asked to indicate on a scale of 1 to 7 if they agree or not with the statements: 1 indicating that they strongly disagree and 7 indicating they strongly agree. Intolerance for ambiguity is tested on a scale that includes twenty items (AT-twenty scale, originally developed by Budner, 1962 and updated by Mac Donald Jr., 1970). Self-esteem is tested on a scale of fourteen items and Locus control is tested with a scale of twelve items that are included in the Entrepreneurial Attitude Orientation (Developed by Robinson et al., 1991). The average of different characteristics was used. A high average indicates that the characteristic is present on the leader. The section of performance measures includes twenty items on the diversity and eleven items on the use of performance measures. Among the twenty items on the diversity of performance measures, eleven items are financial measures and nine items are non-financial measures. Among the eleven items concerning the use of performance measures, five items measure performance monitoring while the other six items measure the use in order to direct attention. The leader was invited to declare if he/she uses much or less performance measures on a scale of 1 (not at all) to 7 (very much).

We used the average of each item in our constructs. A high average indicates a high use of performance measures. Enterprise management performance is evaluated through a series of eight recurring tasks of an enterprise manager (Mahoney, 1967). The leader must indicate on a scale of 1 to 7 if he is below average or above for accomplishing various tasks. A ninth item is also present to assess the overall performance of the leader. This item is used as a control variable in our study.

Various variables were added to the questionnaire in order to be able to control the variation of the enterprise management performance. The variables of controls are present at two levels: (1) the organizational level: size of the company, the age of the company, the influence of recipients and the type of SE and (2) the individual level: formation of the leader, his experience in the company and its specialization. The descriptive statistics and the matrix of correlation of different constructs are presented in table $5 \mathrm{~b}$.

For the data analysis, we used SPSS 15. 


\section{Results}

\subsection{Connection between individual characteristics and performance measures}

First at all statistical analysis of mean comparison was performed to compare the use and the diversity of performance measures according to different individual characteristics. The results are presented in Table 6 . Indeed leaders demonstrating a high degree of self-esteem use performance measures much more intensively in order to monitoring the results than direct the attention. These leaders are regular users of more diverse performance measures, because they use more measures (Financial and nonfinancial) than leaders showing a low degree of self-esteem.

Concerning the locus control, leaders showing external locus control use much performance measures for monitoring the results than to direct attention. Leaders showing external locus control use many financial and nonfinancial measures than leaders showing internal control. All tests are significant at $0.05(\mathrm{p}<0.05)$. The individual characteristic of intolerance for ambiguity has no difference, the use and the diversity as well.

Secondly, we conducted a regression analysis to evaluate the influence of individual characteristics on the diversity and the use of performance measures.

The goal is to identify the characteristics that influence the diversity and the use of performance measures. The first regression equation is: $\quad \mathbf{Y}=\boldsymbol{\alpha}+\boldsymbol{\beta} 1+\boldsymbol{\beta} 2+\boldsymbol{\beta} 3+\boldsymbol{\varepsilon}$

$Y=$ Diversity; $\alpha=$ Constant; $\beta 1=$ Self-esteem; $\beta 2=$ Locus control; $\beta 3=$ Intolerance for ambiguity. In the table 7 , the regression $(\mathrm{r} 2=0,123)$ explains that the variation of the dependent variable (diversity) is significant $(\mathrm{p}<0.05)$. The only variable significant at the 0.05 level is the locus control. This indicates that the locus control has an influence on the diversity of performance measures (see details in table 7).

The second regression equation is: $\quad \mathbf{Y}=\boldsymbol{\alpha}+\boldsymbol{\beta} 1+\boldsymbol{\beta} 2+\boldsymbol{\beta 3}+\boldsymbol{\varepsilon}$

$\mathrm{Y}=$ The use; $\alpha=$ Constant; $\beta 1=$ Self-esteem; $\beta 2=$ Locus control; $\beta 3=$ Intolerance for ambiguity. In the table 8 , the regression $(\mathrm{r} 2=0.130)$ explains that the variation of the dependent variable (the use) is significant $(\mathrm{p}<0.05)$. This indicates that the locus control has an influence on the use of performance measures (see details in table 8).

\subsection{Connection between Performance measures and enterprise management performance}

To test the connection between performance measures and enterprise management performance, we conducted a comparison of means between groups that more use and less use performance measures (diversity and the use). The tests are significant at 0.05 and show that there is a difference between leaders' management performance and the diversity of performance measures, as shown in table 9 and table 10.

Regarding the enterprise management performance and the use of performance measures, the differences are also significant (see the result details in table 11).

Secondly we performed linear regressions to evaluate the influence of the diversity of performance measures, the influence of the use of performance measures including various control variables on enterprises management performance. The control variables used are specialization of the leader, the level of education, enterprise size, the number of years of experience of the leader and the type of SEs.

The regression equation is:

$$
\mathbf{Y}=\alpha+\beta 1+\beta 2+\beta 3+\beta 4+\beta 5+\beta 6+\beta 7+\varepsilon
$$

$Y=$ Enterprise management performance; $\alpha=$ Constant; $\beta 1=$ Diversity of performance measures; $\beta 2=$ The use of performance measure; $\beta 3=$ =Education of the leader; $\beta 4=$ Specialization of the leader; $\beta 4=$ Size of the enterprise (number of employees); $\beta 5=$ annual sale; $\beta 6=$ Type of Small Enterprise; $\beta 7=$ experience of the leader. In the table 12 , the regression $(\mathrm{r} 2=0.195)$ explains that the variation of the dependent variable (enterprise management performance) is significant $(p<0.05)$. Variables explaining enterprise management performance $(p<0.05)$ are the diversity of performance measures and the use of performance measures. None of control variables is significant to explain changes in enterprise management performance (see details in table 12).

\subsection{Connection between individual characteristics, the use, the diversity of performance measures and enterprise management performance}

To validate the relationship between individual characteristics, the use, the diversity of performance measures to explain the performance of the enterprise management, we tested several regression equations. The hypotheses were tested using the model regression moderated regression analysis, as well as with the method of comparison of means to test the connection between different variables. With the comparison tests of mean, the only significant interaction is the one combining self-esteem and the diversity of performance measures (Table 13).

The only significant relationship according to regression testing is performed to intolerance for ambiguity and the diversity of performance measures (Table16).This discrepancy between the results from the comparison of means and regressions is due to the fact that comparison of mean tests performed as first analysis and is less accurate because we put variables into two categories variables while the regression takes into account several level of variables, which can confirm or deny the conclusions obtained by comparisons between average groups. 


\subsubsection{The use of performance measures according to individual characteristics}

The first formulation is for the use of performance measures mainly for monitoring results or direct attention. This variable is not only included in the regression but we add an interaction variable between the individual characteristics and use of performance measures, we add the variables of locus control in the regression

The formulation of the regression is: $\quad \mathbf{Y}=\boldsymbol{\alpha}+\boldsymbol{\beta} 1 \mathbf{X}+\boldsymbol{\beta} 2 \mathbf{S} 1+\boldsymbol{\beta} 3(\mathbf{X} * \mathbf{S} 1)+\mathbf{S} 2+\mathbf{S} 3+\mathbf{S} 4+\mathbf{S 5}+\mathbf{S 6}+\mathbf{S} 7+\mathbf{S} 8+\varepsilon$

$\mathbf{Y}=$ Enterprise management performance; $\mathrm{a}=$ Constant; $\mathrm{X}=$ individual characteristics of the leader; $\mathrm{S} 1=$ The use; $\mathrm{S} 2=$ specialization of the leader; S3=Education of the leader; S4=Size of the enterprise (employees); S5=Size of the enterprise(sales); S6=Age of the SE; S7=type of the SE; S8= experience of the leader

\subsubsection{Intolerance for ambiguity}

In regard to the characteristic of intolerance for ambiguity and the use of performance measures, the regression is significant at $\mathrm{R}^{2}=0.177$. However, when we analyze each explanatory variable included in the regression (table 14) we note that the only explanatory variable is the use of performance measures $(\mathrm{p}<0.05)$.

\subsubsection{Self-esteem}

Self-esteem, as individual characteristic was also tested in regression. The regression is also significant at $\mathrm{R}^{2}=$ 0.242 .However in this regression the only two explanatory significant variables are self-esteem characteristic and the use of performance measures $(\mathrm{P}<0.05)$. Control variables and interaction term are not significant (see table 15)

\subsubsection{Locus Control}

The locus control was finally tested in a regression. The regression is also significant at $R^{2}=0,289$ (table 18).However, in this regression, the same scenario as self-esteem occurs and the only significant variables are locus and the use of performance measures $(\mathrm{P}<0.05)$.

\subsubsection{The diversity of performance measures according to individual characteristics}

The second formulation concerns the diversity of performance measures. We have also included the interaction term and the variables controls in the regression.

The formulation of the regression is: $\mathbf{Y}=\boldsymbol{\alpha}+\mathbf{B 1 X}+\mathbf{B 2 S} 1+\mathbf{B 3}(\mathbf{X} * \mathbf{S} 1)+\mathbf{S} 2+\mathbf{S 3}+\mathbf{S 4}+\mathbf{S} 5+\mathbf{S 6}+\mathbf{S} 7+\mathbf{S} 8+\boldsymbol{\varepsilon}$

$\mathbf{Y}=$ Enterprise management performance; $\mathrm{a}=$ Constant; $\mathrm{X}=$ individual characteristics of the leader; $\mathrm{S} 1=\mathrm{The}$ diversity; $\mathrm{S} 2=$ specialization of the leader; $\mathrm{S} 3=$ Education of the leader; $\mathrm{S} 4=$ Size of the enterprise (employees); $\mathrm{S} 5=$ Size of the enterprise(sales);S6=Age of the SE; S7= type of Small Enterprise;S8=experience of the leader

\subsubsection{Intolerance for ambiguity}

The regression results involving intolerance of ambiguity and diversity performance measures are shown in Table 16.The regression is significant at $\mathrm{R}^{2}=0,291$. The variables diversity of performance measures and the interaction between diversity and intolerance of ambiguity are significant. No other predictor is significant at 0.05 level.

\subsubsection{Self-esteem}

The same regression model was also used, taking into account the individual characteristic of self-esteem (see table 17).The regression is significant at $\mathrm{R}^{2}=0.219$. The only explanatory variable in this case is the diversity of performance measures $(\mathrm{P}<0.05)$

\subsubsection{Locus control}

The locus control's characteristic was also included in a regression including the diversity of performance measures (see table 18). The regression is significant at $\mathrm{R}^{2}=0.289$. The locus control characteristic and the diversity of performance measures are significant $(\mathrm{P}<0.05)$.

\subsection{Discussion}

\subsubsection{Connection between individual characteristics and Performance measures}

The first hypothesis $\left(\mathrm{H}_{1}\right)$ in this research tested the association between intolerance for ambiguity and the diversity of performance measures. The comparison of means between groups leader shows that intolerance for ambiguity is not a factor explaining the diversity of performance measures used. Moreover, the regression performed on this characteristic indicates that the intolerance for ambiguity is not a predictor of the diversity of performance measures (table 12)

The result is the same for the hypothesis $\left(\mathrm{H}_{3}\right)$ that attempted to demonstrate a connection between intolerance for ambiguity and the use of performance measures

This study shows that there is no significant difference between tolerant leaders and intolerant leaders for ambiguity. The Table 8 demonstrates that the intolerance for ambiguity is not an explanatory variable of the use of performance measures.

This lack of difference between tolerant and intolerant leaders for ambiguity can be linked to the measuring 
instrument used to characterize leaders but also by the fact that the leaders of Small enterprises must, according to the type of Small Enterprise, demonstrate higher tolerance for ambiguity than leaders of large enterprises.

Regarding the positive relationship between internal locus control and the diversity of performance measures $\left(\mathrm{H}_{6}\right)$, the results indicate an inverse relationship to the result we had predicted. Indeed leaders showing an external locus control tend to use more diverse performance measures. The Regression for the locus control is a significant predictor $\mathrm{p}<0.05$ (table 8 ).

Regarding the assumption about the internal locus control and the use of performance measures $\left(\mathrm{H}_{5}\right)$, the result of the regression presented in table 8 indicates that the characteristic of locus control is significant at $\mathrm{P}<0.05$ and can explain the use of performance measures.

These results seem to confirm the findings of Fisher (1996) who came to the same conclusion. His research results indicates that the fact that a leader present an internal locus control demonstrate that he believes that he has everything he needs to perform well and develop his enterprise; which is different for the leader presenting an external locus control.

Assumptions about the characteristic of self-esteem indicated that leaders with a low degree of self-esteem were positively associated with the diversity of performance measures (H9) and the use of performance measures (H10). Regarding the comparisons of means, the results indicate that a leader (contrary to our expectations) showing a high degree of self-esteem use more intensively diverse performance measures than a leader showing low degree of self-esteem. Regressions performed on these assumptions and presented in table 7 and table 8 shows, however, the self-esteem is not a predictor of diversity and the use of performance measures.

No explanation was found in the literature about self-esteem assumptions. However, we can attempt explanation of the fact that a leader showing high self-esteem would like to have confirmation that he succeeds in enterprise management ,so more performance measures are used more confirmations will come and thereby the gratitude to the leader.

This need for self-esteem may explain the establishment of more measurement and how the leader uses these measures, while the leader showing low self-esteem would not be tempted to use many performance measures and would not use them in order to direct attention but only to monitoring results.

4.4.2 Connection between performance measures and enterprise management performance

The second objective of this study is to attempt to demonstrate positive association between the diversity and the use of performance measures on enterprise management performance. The hypothesis 13 tested the positive relationship between the diversity of performance measures and enterprise management performance. The linear regression explaining enterprise management performance is presented in table 12.

There is then a positive connection between the diversity of performance measures and enterprise management performance. The hypothesis 14 is also confirmed. This hypothesis tested the positive relationship between the use of performance measures and enterprise management performance (see table 12).

This regression explained $R^{2}=0.195$ of the variation in the dependent variable (enterprise management performance) and is significant at $\mathrm{P}<0.05$.Talking about different explanatory variables, variables explaining enterprise management performance $(\mathrm{p}<0.05)$ are the diversity of performance measures and the use of performance measures. None of the control variables is significant for explaining changes in enterprise management performance (see table 12).

\section{Conclusion}

The aim of this research was to provide an explanation of individual characteristics of Gabonese Small Enterprise leader in connection with the use and the diversity of performance measures. The problematic of this research was: how can the enterprise leader's individual characteristics impact on the Performance Measures Systems? What are the relationship between Performance Measures Systems and the enterprise management performance? In other words these research objectives were: first to demonstrate the connection between SEs leaders' characteristics and PMS; secondly to analyze the relationship between PMS and enterprise management performance.

The research results prove that there is a link between the individual characteristic of locus control and self-esteem and performance measures (the diversity and the use).In other words, they demonstrate that leaders showing an external locus control and a high level of self-esteem use more diverse performance measures.

This research also demonstrates the relationship between PMS (diversity and use) and enterprise management performance.

This study has implications for Gabonese Small Enterprises management practices. We cannot separate SEs leaders' individual characteristics from enterprise management. This research questions about the use and the diversity of PMS according to the individual characteristics present in enterprise leaders.

This study presents several limitations which must be mentioned. The first is the validity of measurement instruments for leaders' individual characteristics. All measurement instruments that we used are valid. However, 
previous studies used several years old instruments, so we can't ensure the validity of their old instruments.

Secondly, enterprise leaders when responding to a survey often make a difference between their individual characteristics and their role as enterprise leader. Moreover, enterprise management performance is evaluated using a subjective method, this measure is then perceptual. It represents the eight tasks of an enterprise leader; however, these tasks are not necessarily representative for all Gabonese leaders who responded to the survey. We hope that this study will contribute to the progress of management performance of Small Enterprises in GABON.

\section{References}

ADB, Gabon. (2009). Study on the Diversification of Sources of Economic Growth, ADB/BD/IF/2009/57.

Amadou BA. (200). The Problematic on the Financial Performance Management of SME in GABON. Planet Finance Advisory Services, (PFAS), 2009.

Atkinson, A., \& Epstein, M. (2000a). Measure for Measure: Realizing the Power of the. Balanced Scorecard. CMA Management, September, pp. 23-27.

Begley, T., \& Boyd, D.P. (1987). Assessing the type a Behavior Pattern with the Jenkins Activity Survey. British Journal of Medical Psychology, 60:155-161.

Bescos P.L. et Cauvin E. (2004). L'évaluation des performances dans les entreprises françaises: une étude empirique, Congrès de l'Association Francophone.

Bititci, U. (1994). Measuring your way to profit. Management Decision, Vol. 32.

Boyd, Lynn H, and James F. Cox. (1997). A cause and effect Approach to analyzing performance Measures. Production and Inventory Management Journal, 38, no. 3 (1997): 25-33.

Brockhaus, R. (1980). Risk taking propensity of entrepreneurs. Academy of Management Journal, (pre-1986).

Budner, S. (1962). Intolerance of ambiguity as a individual characteristics variable. Journal of Individual characteristics, 30(1), 29-51

Burchell et al. (1980). Use of accounting information for decision making. Journal of management accounting research, 16(5) 180-306.

C. Ittner \& D. Larcker. (2005). "Costs and Benefits of Quality Improvement," in M. Maher and R. Weil, Handbook of Cost Management, 2nd Edition, Hoboken, NJ: John Wiley \& Sons, 2005.

Cattell, R. (1949). Individual characteristics tests and measurements. In Patterns for modern living. In D. Society. Chicago.

Chapman. (1997). Reflections on a contingent view of accounting. Accounting, Organizations and Society, 22.

Chenhall, R., H. (2003). Integrative strategy performance measurement Systems, strategy alignment of manufacturing, learning and strategy outcomes: an exploratory study. Accounting, Organizations and Society , 30,395.

Chow, C, W., Haddad, K.M., and Williamson, J.E. (1997). Applying the Balanced Scorecard to Small Companies. Management Accounting, 79(2), pp. 21-29.

Denton, D. Keith. (1995). Effective Measurement Involves Asking the Right Questions. Production and Inventory Management Journal, (1995): 65-67.

Doha Abdelhamid and Alia El Mahdi. (2003). The Small Business Informality Challenge: Lessons learned from country experiences and the road ahead for Egypt, cahiers de recherche 14-2003, Center for Interuniversity Research in Quantitative Economic.

Ducheneaut B. (1995). Enquête sur les PME françaises, Maxima Laurent du Mesnil Editeur.

Dupuy. (1987). Towards new Information Systems for Small Business leader. University of Montpellier Research Paper. Crego.

Epstein \& JF Manzoni. (1998). Performance Measurement and Management Control: A Compendium of Research. London: Elsevier. Epstein, MJ (2003a)

Fisher, C. (1996). The impact of perceived environmental uncertainty and individual differences on management information requirements: a research note. Accounting, Organizations and Society, 21, 362.

Fitzgerald (with S Brignall and R Johnston). (2002). The Involvement of management accountants in Operational Process Change: results from field research; International journal of operations and production management, Vol. 22, No 12.

Fodex. (2009). Towards the performance of Gabonese SMEs. Journal' union, 03/2009.

Franklin Assoumou Ndong. (2003). Gabon's economy: an economy in the wake of its oil. International Solidarity Sherbrooke (Quebec, Canada). February 2003

Gabonik. (2005). La mesure de la performance en entreprise Gabonaise. Edition l'harmattan, 12 février 2005 
Galbraith. (1973). Designing Complex Organizations. Reading, MA: Addison-W.Publishing Company.

Gerdin, J., \& Greve, J. (2004). Forms of contingency fit in managerial accounting research-a critical review. Accounting, Organizations and Society, 29(3-4).

Gerdin, J., \& Grève, J. (2007). Accounting, Organizations and Society, 33 (2008) 995-1009.

Gerdin, J., \& Greve, J. (2007). The appropriateness of statistical methods for testing contingency hypotheses in seventeen management accounting research.

Germain C. (2004). La contingence des systèmes de mesure de la performance : les résultats d'une recherche empirique sur le secteur des PME. Finance, Contrôle, Stratégie, vol.7, n1, Mars, pp. 32-52.

Grau, Micah E. (2008). "Using a Model Municipal Performance Measurement System to Assess Mid-size Texas Cities Systems” (2008). Applied Research Projects, Texas State University-San Marcos; paper 282.

Gregory B. Northcraft and Susan J.Ashford. (1990). The preservation of self in everyday life: The effects of performance expectations and feedback context on feedback inquiry. Organizational Behavior and Human Decision Processes, Volume 47, Issue 1, October 1990, Pages 42-64.

Grepme (1997). Petites et Moyennes Entreprises: Bilans et perspectives: Les presses Inter universitaires. Edition, Economica, Paris.

Hall. (2008). Effect of comprehensive performance measurement systems on role clarity, psychological empowerment and managerial performance. Accounting, Organizations and Society.

Hartmann, F.G.H., \& Naranjo-Gil, D. (2006). La funcion del controller en la gestion publica. Harvard Deusto Finanzas y Contabilidad, 71, 74-80.

HassabElnaby H.R., Said A.A., \& Wier B. (2005). The retention of nonfinancial performance measures in compensation contracts. Journal of Management Accounting Research, 15, 193-223.

Henri, J.-F. (2006). Organizational culture and performance measurement Systems. Accounting, Organizations and Society, 31, 77.

Henri, J.-F. (2006a). Management control systems and strategy: a resource-based perspective. Accounting, Organizations and Society, 31(6).

Hudson, M. Smart, P.A., and Bourne, M. (2001). Theory and Practice in SME performance Measurement Systems. International journal of operations and productions.

IMF. (2002). Ministry of Economy and Finance of Gabon, "Gabonese SMEs challenge”, IMF, 2002.

Ittner, C, D., Larcker, D., F., \& Randall, T. (2003). Performance implications of strategy performance measurement in fmancial services firms. Accounting, Organizations and Society, 28, 715.

J, Galbraith. (1973). Designing Complex Organizations. Reading MA: Addison-Wesley Publishing Co.

Jim Sidanius. (1988). Intolerance of Ambiguity, Conservatism, and Racism: Whose Fantasy, Whose Reality?: A Reply to Ray. International Society of Political Psychology, Vol. 9, No. 2 (Jun., 1988), pp. 309-316.

Julien, P. A and Marchesnay, M. (1996). L’Entrepreneuriat, Economica poche Julien P-A; Marchesnay M. (1988). La petite entreprise, Vuibert

Kalika M. (1987). Structures d'entreprises, réalités, déterminants, performances, Economica.

Kaplan, R. S., \& Norton, D. P. (1992). The Balanced Scorecard-Measures that drive performance. Harvard Business Review, 70(1), 71-81.

KOUNIN J. S. (1948). The meaning of rigidity: a reply to Heinz Werner. Psyc. Rev, 55

Levy M and Powell. (1998). SME Flexibility and the Role of Information Systems. Small Business Economics, 11 (1998).183-196.

Levy, M., \& Powell, P. (1998). SME Flexibility and the rôle of information ystems. Small Business Economies, 11.

Lipe. G.M et Salterio S.E. (2000). The Balanced Scorecard: Judgmental Effects of Common and Unique Performance Measures. The accounting Review, Vol 75, n3, July, pp. 283-299.

Lynch, R \& Cross, K. (1991). Measure Up! Yardsticks for Continuous Improvement. Oxford: Blackwell Publishing.

Mahoney, T.A. (1967). Effectiveness. Management Science fourteen.

Malina, MA \& Selto, FH. (2004). Lifecycle cost Dunk. Journal of management accounting research, 13(4) 441-469.

Marchesnay M \& Julien P-A. (1996). L'entrepreneuriat, Economica poche.

Mc Donald. (1970). Revised scale for ambiguity tolérance: reliability and validity. Psychological Reports.

McClelland DC. (1973). Testing for competence rather than for intelligence. American Psychologist, 28: 1-14. 
McGhee., Shields, M.D., \& Birnberg. (1978). The Effects of Personality on a Subject's Information Processing. The Accounting Review, 5, 3.

Ministry of SME of Gabon. (2010). Répertoire des Petites et Moyennes Entreprises Gabonaises: Annuaire: Ministère des Petites et Moyennes Entreprises du GABON, 2010

Mostafa Abakouy. (2006). Performances à l'international de la PME marocaine.

Naranjo Gil, and Hartmann. (2006b). Management accounting Systems, top management team heterogeneity and stratégie change. Accounting, Organizations and Society.

P.L.Bescos \& Cauvin E. (2004). L'évaluation des performances dans les entreprises françaises : une étude empirique. Congrès de l'Association Francophone de Comptabilité, Orléans.

Panapress. (2008). Les petites et moyennes entreprises Gabonaises. Numéro hebdomadaire de février, 2008. PP24-36.

Riggs \& Bracker, (1986). Operations management and financial performance. Entrepreneurship Theory and Practice, 10(3), 17-23.

Robson, Ian. (2005). Implementing a Performance Measurement System Capable of Creating a Culture of High Performance. International Journal of Productivity and Performance Management, 54. 1-2 (2005): 137-145.

Rokeach. (1960). The study of human values. Journal of management accounting research, 15(4) 320-400.

Rotter, J. B. (1966). Generalized expectancies for internal versus external control of reinforcement. Journal of individual characteristics, 30(2), 32-54.

RS, Chong. (1998). Modeling dual-task performance improvement: Casting executive process knowledge acquisition as strategy refinement.

S.K., Widener. (2007). An empirical analysis of the levers of control framework. Accounting, Organizations and Society, 32 (7-8), pp. 757-788.

Said A. A., HassabElnaby H. R., \& Wier B. (2003). An empirical investigation of the performance consequences of non financial measures. Journal of Management Accounting Research, 15, pp.193-223.

Simon, H.A., Guetzkow, H., K, G., \& T, G. (1954). Centralization vs decentralization in organizing the controllers. Department. Controllership Foundation .

Simons. (1990). The Rôle of Management Control Systems in Creating Compétitive Advantage: New Perspectives; The Enactment of Management Control Systems: A Critique of Simons. Accounting, Organizations and Society, 15. Republic of Gabon, Growth and Poverty Reduction Strategy Paper, 2006, PP.1-50

Tangen, Stefan. (2004). Performance Measurement: From Philosophy to Practice. International Journal of Productivity and Performance Management, 53, no. 8: 726.

The Directorate General of Statistics and Economic Studies review (DGSE), Gabon, 2010, pp.215-300.

United Nations. (2001). Enhancing African SME access to credit. Development Strategies and Support services for SMEs: Proceedings of Four Intergovernmental Expert meeting, Vol.II, New York and Geneva: United Nations, pp.125-133.

Webb, R. (2004). Managers 'commitment to the goals contained in a strategic performance system. Contemporary Accounting Research, Vol.21, N4, pp. 925-958.

Widener. (2007). An empirical analysis of the levers of control framework. Accounting, Organizations and Society, 32, 758.

Willy ONTSIA. (2007). État Gabonais 5, 50\% net 2007-2013.

Wisner, J.D., and S.E. Fawcett. (1991). Link Firm Strategy to Operating Decisions through Performance Measurement. Production and Inventory Management Journal, 32, no.3 (1991): 5-11.

Table 1. Steps for questionnaires mailing

\begin{tabular}{|l|l|l|}
\hline Survey & Questionnaire number & Percentage \\
\hline First mailing & 116 & $48,94 \%$ \\
Second mailing & 121 & $51,05 \%$ \\
Total & 237 & $100 \%$ \\
\hline
\end{tabular}

Description for table 1: Among the 237 questionnaires for the survey, 116 were received after the first mailing, 121 were received after the second mailing 
Table 2. T-test for non response bias by age of enterprise

\begin{tabular}{|c|c|c|c|c|c|c|c|c|c|}
\hline & \multicolumn{2}{|c|}{$\begin{array}{l}\text { Test for equality of } \\
\text { variances }\end{array}$} & \multicolumn{7}{|c|}{ Test for equality of means } \\
\hline & \multirow[t]{2}{*}{$\mathrm{F}$} & \multirow[t]{2}{*}{ Sig } & \multirow[t]{2}{*}{$\mathrm{t}$} & \multirow[t]{2}{*}{ df } & \multirow[t]{2}{*}{ Sig } & \multirow[t]{2}{*}{$\begin{array}{l}\text { Mean } \\
\text { difference }\end{array}$} & \multirow[t]{2}{*}{$\begin{array}{l}\text { Standard error of } \\
\text { difference }\end{array}$} & $\begin{array}{l}95 \% \\
\text { interval }\end{array}$ & Confidence \\
\hline & & & & & & & & Low & High \\
\hline $\begin{array}{l}\text { Age Equal } \\
\text { variances assumed }\end{array}$ & 1,235 &, 250 & ,757 & 1908 & ,451 &, 725 & ,957 & $-1,154$ & 2,601 \\
\hline $\begin{array}{l}\text { Variances not } \\
\text { assumed }\end{array}$ & & & ,674 & 280,3 & ,502 &, 725 & 1,075 & $-1,391$ & 2,838 \\
\hline
\end{tabular}

Description for table 2: We found no significant difference at $\mathrm{P}<0.05$ between the averages of two groups $(0$ being the group which did not respond and 1 being the group that responded to the survey).In regard to the different industries represented in the sample; we can say that there is no nonresponse bias.

Table 3. $T$ test for nonresponse bias by enterprise size

\begin{tabular}{|c|c|c|c|c|c|c|c|c|c|}
\hline \multirow{3}{*}{ Emp.Equal } & \multicolumn{2}{|c|}{$\begin{array}{l}\text { Test for equality of } \\
\text { variances }\end{array}$} & \multicolumn{7}{|c|}{ Test for equality of means } \\
\hline & \multirow[t]{2}{*}{$\mathrm{F}$} & \multirow[t]{2}{*}{ Sig } & \multirow[t]{2}{*}{$\mathrm{t}$} & \multirow[t]{2}{*}{ df } & \multirow[t]{2}{*}{ Sig } & \multirow[t]{2}{*}{$\begin{array}{l}\text { Mean } \\
\text { difference }\end{array}$} & \multirow[t]{2}{*}{$\begin{array}{l}\text { Standard error of } \\
\text { difference }\end{array}$} & \multicolumn{2}{|l|}{$\begin{array}{l}95 \% \\
\text { interval }\end{array}$} \\
\hline & & & & & & & & Low & High \\
\hline variances assumed & 2,391 & ,123 & ,-1,556 & 1999 & ,121 & ,-2578 & 1,668 & $-6,828$ & 674 \\
\hline $\begin{array}{l}\text { Equal variances } \\
\text { not assumed }\end{array}$ & & & 1,454 & 291,60 & , 148 & -2578 & 1,774 & $-6,068$ & ,915 \\
\hline
\end{tabular}

Description for table 3: We found no significant difference at $\mathrm{P}<0.05$ between the averages of two groups $(0$ being the group which did not respond and 1 being the group that responded to the survey).In regard to the different industries represented in the sample; we can say that there is no nonresponse bias.

Table 4. Test for nonresponse bias by enterprise respondents

\begin{tabular}{|l|l|l|l|}
\hline \multicolumn{4}{|c|}{ Chi-Square Test } \\
\hline Pearson Chi-Square & Value & Df & Signification(bilateral) \\
\hline & 10,871 & 13 &, 541 \\
\hline Pobability ratio & 12,591 & 13 &, 401 \\
\hline Linear association &, 102 & 1 &, 751 \\
\hline Number of valid box & 2000 & & \\
\hline
\end{tabular}

Description for table 4: Chi-square is not significant at $\mathrm{P}<0.05$

Table 5a. Number of employees per enterprise

\begin{tabular}{|l|l|l|l|l|l|l|l|l|}
\hline $\begin{array}{l}\text { Number of } \\
\text { Employees }\end{array}$ & $\begin{array}{l}\text { Number of } \\
\text { Enterprises }\end{array}$ & $\%$ & $\begin{array}{l}\text { Number of } \\
\text { Employees }\end{array}$ & $\begin{array}{l}\text { Number of } \\
\text { Enterprises }\end{array}$ & $\%$ & $\begin{array}{l}\text { Number of } \\
\text { Employees }\end{array}$ & $\begin{array}{l}\text { Number of } \\
\text { Enterprises }\end{array}$ & $\%$ \\
\hline 1 to 6 & 17 & 7.17 & 7 to 10 & 56 & 23.62 & 11 to14 & 33 & 13.92 \\
\hline 15 to 19 & 24 & 10.12 & 20 to 25 & 16 & 6.75 & 26 to 32 & 14 & 5.90 \\
\hline 33 to 36 & 12 & 5.06 & 37 to 41 & 11 & 4.64 & 42 to 47 & 3 & 1.26 \\
\hline 48 to 50 & 5 & 2.10 & 51 to 57 & 3 & 1.26 & 58 to 65 & 6 & 2.53 \\
\hline 66 to 67 & 2 & 0.84 & 68 to 72 & 2 & 0.84 & 73 to 83 & 2 & 0.84 \\
\hline 84 to 88 & 7 & 2.95 & 89 to 90 & 5 & 2.10 & 91 to 120 & 6 & 2.53 \\
\hline 121 to 151 & 4 & 1.68 & 152 to 203 & 4 & 1.68 & 202 to 348 & 5 & 2.10 \\
\hline
\end{tabular}

Description for table 5a: Respondents employ between 1 and 348 employees

Table 5b. Experience of the respondents

\begin{tabular}{|l|l|l|l|l|l|l|l|l|}
\hline $\begin{array}{l}\text { Number of } \\
\text { Employees }\end{array}$ & $\begin{array}{l}\text { Number of } \\
\text { Enterprises }\end{array}$ & $\%$ & $\begin{array}{l}\text { Number of } \\
\text { Employees }\end{array}$ & $\begin{array}{l}\text { Number of } \\
\text { Enterprises }\end{array}$ & $\%$ & $\begin{array}{l}\text { Number of } \\
\text { Employees }\end{array}$ & $\begin{array}{l}\text { Number of } \\
\text { Enterprises }\end{array}$ & $\%$ \\
\hline 1 to 6 & 25 & 10.55 & 7 to 10 & 44 & 18.56 & 11 to 14 & 70 & 29.53 \\
\hline 15 to 19 & 33 & 13.92 & 20 to 25 & 24 & 10.12 & 26 to 32 & 22 & 9.28 \\
\hline 33 to 36 & 8 & 3.37 & 37 to 41 & 4 & 1.68 & 42 to 47 & 1 & 0.42 \\
\hline 48 to 50 & 1 & 0.42 & 51 to 57 & 1 & 0.42 & 58 to 65 & 3 & 1.26 \\
\hline 66 & 1 & 0.42 & & & & & & \\
\hline
\end{tabular}

Description for table 5b: The experience of respondents in their current position ranged from 1 year to 66 years old 
Table 5c. Type of enterprise

\begin{tabular}{|l|l|l|l|}
\hline & Family & Non-family & Total \\
\hline Frequency & 89 & 148 & 237 \\
\hline Percentage & $37.55 \%$ & $62.44 \%$ & $100 \%$ \\
\hline
\end{tabular}

Description for table 5c: Over 30 percent of enterprises which responded are family businesses

Table $5 \mathrm{~d}$. Turnovers of respondents

\begin{tabular}{|l|l|l|l|l|l|l|l|l|}
\hline $\begin{array}{l}\text { Turnovers } \\
\text { (Millions \$) }\end{array}$ & $\begin{array}{l}\text { Number of } \\
\text { Enterprises }\end{array}$ & $\%$ & $\begin{array}{l}\text { Turnovers } \\
\text { (Millions \$) }\end{array}$ & $\begin{array}{l}\text { Number of } \\
\text { Enterprises }\end{array}$ & $\%$ & $\begin{array}{l}\text { Turnovers } \\
\text { (Millions \$) }\end{array}$ & $\begin{array}{l}\text { Number of } \\
\text { Enterprises }\end{array}$ & $\%$ \\
\hline 8 & 42 & 17.72 & 9 to 10 & 12 & 5.06 & 11 to 12 & 12 & 5.06 \\
\hline 13 to 14 & 20 & 8.44 & 15 to 16 & 36 & 15.19 & 17 to 18 & 12 & 5.06 \\
\hline 19 to 20 & 34 & 14.34 & 21 to 22 & 11 & 4.64 & 23 to 24 & 8 & 3.37 \\
\hline 25 to26 & 15 & 6.33 & 27 to 28 & 21 & 8.86 & 29 to 30 & 14 & 5.9 \\
\hline
\end{tabular}

Description for table 5d: Respondents have turnovers are ranging from $\$ 80.000$ to 30 million

Table 5e. Age of enterprises

\begin{tabular}{|c|c|c|c|c|c|c|c|c|}
\hline $\begin{array}{c}\text { Age of } \\
\text { enterprises }\end{array}$ & $\begin{array}{c}\text { Number of } \\
\text { enterprises }\end{array}$ & $\%$ & $\begin{array}{c}\text { Age of } \\
\text { enterprises }\end{array}$ & $\begin{array}{c}\text { Number of } \\
\text { enterprises }\end{array}$ & $\%$ & $\begin{array}{c}\text { Age of } \\
\text { enterprises }\end{array}$ & $\begin{array}{c}\text { Number of } \\
\text { enterprises }\end{array}$ & $\begin{array}{c}\% \\
\%\end{array}$ \\
\hline 2 to 6 & 9 & 3.79 & 6 to 10 & 9 & 3.79 & 11 to 16 & 95 & 40.08 \\
\hline 17 to 21 & 35 & 17.76 & 22 to 26 & 10 & 4.22 & 27 to 31 & 22 & 9.28 \\
\hline 32 to 36 & 11 & 4.64 & 36 to 40 & 8 & 3.37 & 41 to 45 & 1 & 0.42 \\
\hline 46 to 50 & 1 & 0.42 & 51 to 55 & 6 & 2.53 & 56 to 60 & 1 & 0.42 \\
\hline 61 to 65 & 6 & 2.53 & 66 to 70 & 8 & 3.37 & 71 to 75 & 1 & 0.42 \\
\hline 76 to 80 & 14 & 5.9 & & & & & & \\
\hline
\end{tabular}

Description for table 5r: Enterprises ages are ranging from 2 to 80 years

Table $5 f$. Frequency of respondents 'diplomas

\begin{tabular}{|l|l|l|}
\hline & Business Admin & Sales and Marketing \\
\hline Frequency & 88 & 149 \\
\hline Percentage & $31.13 \%$ & $62.87 \%$ \\
\hline
\end{tabular}

Table 5g. Respondents' education background

\begin{tabular}{|l|l|l|}
\hline & Business Admin & Sales and Marketing \\
\hline Frequency & 110 & 127 \\
\hline Percentage & $46.41 \%$ & $53.60 \%$ \\
\hline
\end{tabular}

Table 5h. Provenance of the respondents

\begin{tabular}{|c|c|c|c|c|}
\hline & original sample & $\%$ & Respondents & $\%$ \\
\hline Libreville & 1200 & 60 & 150 & 63.29 \\
\hline Port-Gentil & 801 & 40 & 87 & 36.71 \\
\hline Total & 2001 & 100 & 237 & 100 \\
\hline
\end{tabular}

Table 5i. Respondents' industries

\begin{tabular}{|l|l|l|l|l|}
\hline Sector of activity of Enterprises & Samples & & & \\
\hline Food \& Beverage Manufacturing & 400 & 99.99 & 50 & 21.09 \\
\hline Textile products & 425 & 21.23 & 6 & 2.53 \\
\hline Crafts & 334 & 16.69 & 20 & 8.44 \\
\hline Plastic products manufacturing & 300 & 14.99 & 88 & 37.13 \\
\hline Petroleum products manufacturing & 200 & 9.99 & 56 & 23.63 \\
\hline Mineral products manufacturing & 342 & 17.09 & 17 & 7.17 \\
\hline Total & 2001 & $100 \%$ & 237 & $100 \%$ \\
\hline
\end{tabular}

Description for table 5i: Food \& Beverage manufacturing and Textile products business constitute the favorite business for some Small Enterprises. 
Table $5 \mathrm{~g}$. The descriptive statistics and the matrix of correlation of different constructs

\begin{tabular}{|c|c|c|c|c|c|c|}
\hline \multicolumn{4}{|c|}{ Correlation matrix (Pearson) } & \multirow[b]{2}{*}{ Self-esteem } & \multirow[b]{2}{*}{$\begin{array}{l}\text { Locus } \\
\text { control }\end{array}$} & \multirow[b]{2}{*}{$\begin{array}{c}\text { Enterprise } \\
\text { management } \\
\text { performance }\end{array}$} \\
\hline & Diversity & The use & $\begin{array}{l}\text { Intolerance } \\
\text { for } \\
\text { ambiguity }\end{array}$ & & & \\
\hline Diversity & 1 & & & & & \\
\hline The use &, $573 * *$ & 1 & & & & \\
\hline Intolerance & $-0,12$ &,- 104 & 1 & & & \\
\hline Esteem &, $262 * *$ & $266 * *$ &, 066 & 1 & & \\
\hline $\begin{array}{l}\text { Locus } \\
\text { control }\end{array}$ &, $339 * *$ &, $352 * *$ &,$- 228 * *$ &, $588 * *$ & 1 & \\
\hline $\begin{array}{l}\text { Enterprise } \\
\text { management } \\
\text { performance }\end{array}$ &, $373 * *$ &, $414 * *$ & ,009 &, $363 * *$ &, $503 * *$ & 1 \\
\hline
\end{tabular}

Description for table $5 \mathrm{~b}:{ }^{*} \mathrm{p}<0.05$

$$
* * \mathrm{p}<0.05
$$

\begin{tabular}{|l|c|c|c|c|c|c|}
\hline & Diversity & The use & $\begin{array}{c}\text { Intolerance } \\
\text { for } \\
\text { ambiguity }\end{array}$ & Self-esteem & $\begin{array}{c}\text { Locus } \\
\text { control }\end{array}$ & $\begin{array}{c}\text { Enterprise } \\
\text { management } \\
\text { performance }\end{array}$ \\
\hline Original items & 20 & 11 & 20 & 13 & 12 & 8 \\
\hline Used items & 20 & 11 & 14 & 13 & 10 & 8 \\
\hline Scale & $1-7$ & $1-7$ & $1-7$ & $1-7$ & $1-7$ & $1-7$ \\
\hline Minimum & 1,40 & 1,36 & 1,71 & 2,08 & 1,10 & 2,25 \\
\hline Maximum & 6,90 & 7,00 & 6,00 & 6,77 & 7,00 & 7,00 \\
\hline Mean & 4,349 & 5,110 & 3,648 & 5,306 & 5,356 & 5,218 \\
\hline $\begin{array}{l}\text { Standard } \\
\text { deviation }\end{array}$ & 1,186 & 1,239 &, 731 &, 658 &, 794 &, 747 \\
\hline Median & 4,450 & 5,183 & 3,571 & 5,309 & 5,400 & 5,250 \\
\hline Cronbach's alpha &, 899 &, 928 &, 633 &, 630 &, 731 &, 790 \\
\hline
\end{tabular}

Table 6. Comparison of the diversity and the use according to individual characteristics

\begin{tabular}{|c|c|c|c|c|c|c|c|c|}
\hline & \multicolumn{4}{|c|}{ Diversity } & \multicolumn{3}{c|}{ The use } \\
\cline { 2 - 9 } & \multicolumn{2}{|c|}{$\begin{array}{c}\text { Financial } \\
\text { Measures }\end{array}$} & \multicolumn{2}{c|}{$\begin{array}{c}\text { Nonfinancial } \\
\text { Measures }\end{array}$} & \multicolumn{2}{c|}{$\begin{array}{c}\text { Performance } \\
\text { Measures }\end{array}$} & \multicolumn{2}{c|}{$\begin{array}{c}\text { Direct } \\
\text { attention }\end{array}$} \\
\hline Self-esteem & $4,5363^{*}$ & $5,0093^{*}$ & $3,6034^{*}$ & $4,3372^{*}$ & $5,0775^{*}$ & $5,6561^{*}$ & $4,68137^{*}$ & $5,2021^{*}$ \\
\hline Locus control & $4,4512^{*}$ & $5,5012^{*}$ & $5,1033^{*}$ & 4,2897 & $5,0649^{*}$ & $5,6611^{*}$ & $4,6232^{*}$ & $5,3095^{*}$ \\
\hline $\begin{array}{c}\text { Intolerance } \\
\text { for ambiguity }\end{array}$ & 4,8031 & 4,7620 & 40,0811 & 3,9775 & 5,4934 & 5,2502 & 5,0847 & 4,8517 \\
\hline
\end{tabular}

Description for table 6: * Significant at 0.05. All tests are significant at $0.05(\mathrm{p}<0.05)$. The individual characteristic of intolerance for ambiguity has no difference, the use and the diversity as well. 
Table 7. Regression results explaining the diversity of Performance measures

\begin{tabular}{|c|c|c|c|c|c|}
\hline \multicolumn{6}{|c|}{ Coefficients $^{\mathrm{a}}$} \\
\hline \multirow[t]{2}{*}{ Mode } & \multicolumn{2}{|c|}{$\begin{array}{l}\text { Non-standardized } \\
\text { Coefficients }\end{array}$} & \multirow{2}{*}{$\begin{array}{l}\text { Standardized } \\
\text { Coefficients } \\
\text { Beta } \\
\end{array}$} & \multirow[t]{2}{*}{$\mathrm{t}$} & \multirow[t]{2}{*}{ Sig. } \\
\hline & B & Std error & & & \\
\hline 1 (Constant) & 4,350 & 0.75 & & 58,678 &, 000 \\
\hline Self-esteem &, 144 & ,145 & $.08 \mathrm{c}$ & ,993 & ,323 \\
\hline Locus control & ,456 &, 123 & .305 & 3,713 &, 000 \\
\hline Intolerance for ambiguity & 0.85 & , 108 & .053 &, 776 &, 440 \\
\hline
\end{tabular}

a. Dependent variable: Diversity

\begin{tabular}{|l|l|l|l|l|}
\hline Model & $\mathrm{R}$ & Squared R & Adjusted Squared R & Estimation of standard error \\
\hline 1 &, 351 &, 123 &, 112 & 1,11661 \\
\hline
\end{tabular}

a. Predicators: (constant), self-esteem, locus control, intolerance for ambiguity

Description for table 7: The regression $\left(\mathrm{r}^{2}=0.123\right)$ explains that the variation of the dependent variable (diversity) is significant $(<0.05)$. The only variable significant at the 0.05 level is the locus control. This indicates that the locus control has an influence on the diversity of performance measures.

Table 8. Regression results explaining the use of Performance measures

\begin{tabular}{|c|c|c|c|c|c|}
\hline \multicolumn{6}{|c|}{ Coefficients $^{\mathrm{a}}$} \\
\hline \multirow[t]{2}{*}{ Mode } & \multicolumn{2}{|c|}{$\begin{array}{l}\text { Non-standardized } \\
\text { Coefficients }\end{array}$} & $\begin{array}{l}\text { Standardized } \\
\text { Coefficients }\end{array}$ & \multirow[t]{2}{*}{$\mathrm{t}$} & \multirow[t]{2}{*}{ Sig. } \\
\hline & B & Std error & Beta & & \\
\hline 1 (Constant) & 5,111 & 0,78 & & 66,235 &, 000 \\
\hline Self-esteem & ,199 & , 151 &, 106 & 1,319 &, 190 \\
\hline Locus control & ,435 &, 128 & ,279 & 3,408 &, 002 \\
\hline Intolerance for ambiguity & $-0,82$ & ,113 &,- 049 &,- 718 & ,475 \\
\hline
\end{tabular}

\begin{tabular}{|l|l|l|l|l|}
\hline Model & $\mathrm{R}$ & Squared R & Adjusted Squared R & Estimation of standard error \\
\hline 1 &, $361^{\mathrm{a}}$ &, 130 &, 119 & 1,16245 \\
\hline
\end{tabular}

a. Predicators: (constant), self-esteem, locus control, intolerance for ambiguity

Description for table 8: the regression $\left(\mathrm{r}^{2}=0.130\right)$ explains that the variation of the dependent variable (the use) is significant $(\mathrm{p}<0.05)$. This indicates that the locus control has an influence on the use of performance measures.

Table 9. Division to the median according to the diversity of performance measures

\begin{tabular}{|c|c|c|c|c|c|}
\hline \multicolumn{6}{|c|}{ Group statistics } \\
\hline \multicolumn{2}{|c|}{ Diversity } & $\mathrm{N}$ & Mean & $\begin{array}{l}\text { Standard } \\
\text { deviation }\end{array}$ & $\begin{array}{c}\text { Standard } \\
\text { error of } \\
\text { mean }\end{array}$ \\
\hline Enterprise & $>=4,46$ & 113 & 5,3896 & ,68605 & ,06483 \\
\hline $\begin{array}{l}\text { management } \\
\text { performance }\end{array}$ & $<4,46$ & 116 & 5,0517 & ,76953 & ,07177 \\
\hline
\end{tabular}

Description for table 9: the tests are significant at 0.05 and show that there is a difference between leaders' management performance and the diversity of performance measures 
Table 10. Comparison test of means between groups of leaders on the diversity of performance measures

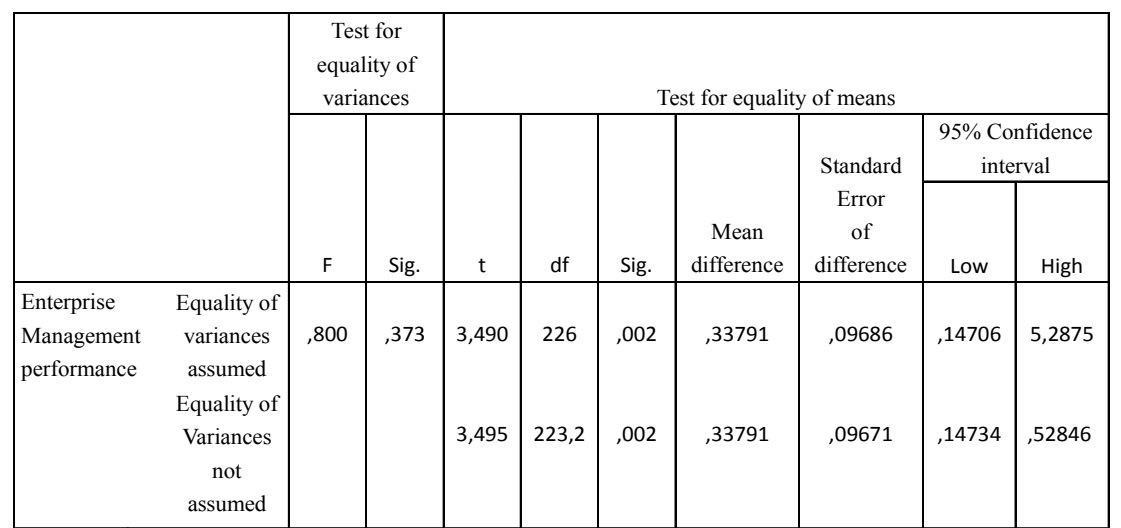

Note for table 10: the tests are significant at 0.05 and show that there is a difference between leaders' management performance and the diversity of performance

Table 11. Comparison test of means between groups of leaders regarding the use of performance measures

\begin{tabular}{|c|c|c|c|c|c|c|c|c|c|c|}
\hline & \multicolumn{2}{|c|}{$\begin{array}{c}\text { Test for } \\
\text { equality of } \\
\text { variances }\end{array}$} & \multicolumn{7}{|c|}{ Test for equality of means } \\
\hline & & \multirow[b]{2}{*}{$\mathrm{F}$} & \multirow[b]{2}{*}{ Sig. } & \multirow[b]{2}{*}{$t$} & \multirow[b]{2}{*}{ df } & \multirow[b]{2}{*}{ Sig. } & \multirow[b]{2}{*}{$\begin{array}{c}\text { Mean } \\
\text { difference }\end{array}$} & \multirow{2}{*}{$\begin{array}{l}\text { Standard } \\
\text { Error } \\
\text { of } \\
\text { difference }\end{array}$} & \multicolumn{2}{|c|}{$\begin{array}{c}95 \% \text { Confidence } \\
\text { interval }\end{array}$} \\
\hline & & & & & & & & & Low & High \\
\hline \multirow[t]{2}{*}{$\begin{array}{l}\text { Enterprise } \\
\text { Management } \\
\text { performance }\end{array}$} & $\begin{array}{c}\text { Equality of } \\
\text { variances } \\
\text { assumed }\end{array}$ & 3,126 & ,080 & 5,704 & 226 & ,000 & ,53276 & 09343 & 34868 & ,71684 \\
\hline & $\begin{array}{c}\text { Equality of } \\
\text { Variances } \\
\text { not } \\
\text { assumed }\end{array}$ & & & 5,506 & 195,5 & ,000 & ,53276 & 09523 & 34496 & ,72055 \\
\hline
\end{tabular}

Note for table 11: Regarding the enterprise management performance and the use of performance measures, the difference is significant

Table 12. Regression results explaining the enterprise management performance

Coefficients $^{\mathrm{a}}$

\begin{tabular}{|c|c|c|c|c|c|c|}
\hline & & \multicolumn{2}{|c|}{$\begin{array}{c}\text { Non-standardized } \\
\text { coefficients }\end{array}$} & \multirow{2}{*}{$\begin{array}{c}\text { Standardized } \\
\text { coefficients }\end{array}$} & \multirow[b]{2}{*}{$\mathrm{t}$} & \multirow[b]{2}{*}{ Sig. } \\
\hline \multicolumn{2}{|c|}{ Model } & B & Std error & & & \\
\hline & (Constant) & 3,935 & 2,79 & & 14,159 & ,000 \\
\hline & Diversity & 120 & ,057 & 193 & 2,141 & ,035 \\
\hline & The use & 157 & ,053 & 270 & 3,006 & ,004 \\
\hline & Study level &,- 188 & 111 &,- 127 & $-1,705$ & ,091 \\
\hline & Specialization & ,001 & ,092 & ,002 & ,017 & 989 \\
\hline & Employees &,- 003 & ,004 &,- 089 &,- 793 & ,430 \\
\hline & Annual sales & 011 & ,011 & 119 & 1,054 & 295 \\
\hline & Private enterp. &,- 064 & 115 &,- 042 &,- 553 & ,583 \\
\hline & Leader's exper. & ,003 & ,007 & ,039 & ,528 & 600 \\
\hline
\end{tabular}

a. Dependent variable: Enterprise management performance

\begin{tabular}{|c|c|c|c|c|}
\hline Model & $\mathrm{R}$ & Squared R & $\begin{array}{c}\text { Adjusted } \\
\text { squared R }\end{array}$ & $\begin{array}{c}\text { Estimation of } \\
\text { standard error }\end{array}$ \\
\hline 1 &, $442^{\mathrm{a}}$ &, 195 &, 155 &, 68563 \\
\hline
\end{tabular}

a. Predicators: (constant), diversity, the use, study level, employees, annual sales, private enterp., leader's exper. 
Note for table 12: the regression $(\mathrm{r} 2=0.195)$ explains that the variation of the dependent variable (enterprise management performance) is significant $(p<0.05)$.Variables explaining enterprise management performance $(p$ $<0.05)$ are the diversity of performance measures and the use of performance measures. None of control variables is significant to explain changes in enterprise management performance

Table 13. Comparison of the enterprise management performance according to different individual characteristics, the use and the diversity of performance measures

\begin{tabular}{|l|l|l|}
\hline Enterprise management Performance \\
\hline Diversity(-) & 4,695 & 5,406 \\
\hline Diversity(+) & 5,288 & 5,481 \\
\hline O,025* & Esteem(-) & Esteem(+) \\
\hline Enterprise management Performance \\
\hline Diversity(-) & 4,723 & 5,407 \\
\hline Diversity(+) & 5,204 & 5,512 \\
\hline O,136* & Locus(-) & Locus(+) \\
\hline Enterprise management Performance \\
\hline Diversity(-) & 5,040 & 5,058 \\
\hline Diversity(+) & 5,320 & 5,320 \\
\hline O,623 & Intoler(-) & Intoler(+) \\
\hline Enterprise management Performance \\
\hline The use(-) & 4,777 & 5,175 \\
\hline The use(+) & 5,291 & 5,588 \\
\hline O,625 & Esteem(-) & Esteem(+) \\
\hline Enterprise management Performance \\
\hline The use(-) & 4,750 & 5,201 \\
\hline The use(+) & 5,242 & 5,615 \\
\hline O,708 & Locus(-) & Locus(+) \\
\hline Enterprise management Performance \\
\hline The use(-) & 4,984 & 4,880 \\
\hline The use(+) & 5,432 & 5,485 \\
\hline O,401 & Intoler(-) & Inter(+) \\
\hline
\end{tabular}

Note for table 13: the only significant interaction is the one combining self-esteem and the diversity of performance measures.

Table 14. Regression with interaction term for intolerance for ambiguity and the use of performance measures

\begin{tabular}{|c|c|c|c|c|c|c|}
\hline \multicolumn{7}{|c|}{ Coefficients $^{\mathrm{a}}$} \\
\hline \multirow{2}{*}{\multicolumn{2}{|c|}{ Model }} & \multicolumn{2}{|c|}{$\begin{array}{l}\text { Non-standardized } \\
\text { coefficients }\end{array}$} & \multirow{2}{*}{$\begin{array}{c}\begin{array}{c}\text { Standardized } \\
\text { coefficients }\end{array} \\
\text { Beta } \\
\end{array}$} & \multirow[b]{2}{*}{$\mathrm{t}$} & \multirow[b]{2}{*}{ Sig. } \\
\hline & & B & Std error & & & \\
\hline \multirow[t]{10}{*}{1} & (Constant) & 4,134 & ,276 & & 15,016 & ,000 \\
\hline & Intol.for ambig. &,- 174 & 273 & -168 &,- 638 & ,526 \\
\hline & The use & ,218 & ,044 & ,375 & 4,999 & ,000 \\
\hline & Interaction & ,043 & ,053 & 211 & ,807 & 423 \\
\hline & Specialization &,- 027 & 093 &,- 022 &,- 278 & 784 \\
\hline & Study level &,- 189 & 113 &,- 128 & $-1,684$ & ,095 \\
\hline & Employees &,- 003 & ,004 &,- 099 &,- 870 & 387 \\
\hline & Annual sales & ,013 & ,011 & 142 & 1,250 & ,214 \\
\hline & Private enterp. &,- 055 & 116 &,- 037 &,- 469 & 641 \\
\hline & Leader's exper. & ,005 & ,007 & ,054 & 724 & 472 \\
\hline
\end{tabular}

a. Dependent variable: Enterprise management performance

\begin{tabular}{|c|c|c|c|c|}
\hline Model & $\mathrm{R}$ & Squared R & $\begin{array}{c}\text { Adjusted } \\
\text { squared R }\end{array}$ & $\begin{array}{c}\text { Estimation of } \\
\text { standard error }\end{array}$ \\
\hline 1 &, $420^{\mathrm{a}}$ &, 177 &, 130 &, 69568 \\
\hline
\end{tabular}

a. Predicators: (constant), intol.for ambig., the use, interaction, study level, employees, annual sales, private enterp., leader's exper.

Note for table 14: the regression is significant at $\mathrm{R} 2=0.177$. However, when we analyze each explanatory variable included in the regression, we note that the only explanatory variable is the use of performance measures $(\mathrm{p}<0.05)$. 
Table 15. Regression with interaction term for self-esteem and the use of performance measures

\begin{tabular}{|c|c|c|c|c|c|c|}
\hline \multicolumn{7}{|c|}{ Coefficients $^{\mathrm{a}}$} \\
\hline \multirow{2}{*}{\multicolumn{2}{|c|}{ Model }} & \multicolumn{2}{|c|}{$\begin{array}{l}\text { Non-standardized } \\
\text { coefficients }\end{array}$} & \multirow{2}{*}{$\begin{array}{c}\begin{array}{c}\text { Standardized } \\
\text { coefficients }\end{array} \\
\text { Beta }\end{array}$} & \multirow[b]{2}{*}{$\mathrm{t}$} & \multirow[b]{2}{*}{ Sig. } \\
\hline & & B & Std error & & & \\
\hline 1 & (Constant) & 4,347 & ,274 & & 15,867 &, 000 \\
\hline & Self-esteem &, 527 & ,264 & ,485 & 2,005 & ,048 \\
\hline & The use & 175 & ,044 & , 304 & 4,200 & , 000 \\
\hline & Interaction &,- 054 & ,055 &,- 240 & -999 & 320 \\
\hline & Specialization &,- 047 & 091 &,- 039 &,- 514 & ,610 \\
\hline & Study level & -168 & 110 &,- 114 & $-1,536$ & 128 \\
\hline & Employees &,- 003 & ,004 & ,068 &,- 607 &, 546 \\
\hline & Annual sales & 008 & 114 &,- 095 & 851 & ,397 \\
\hline & Age of enterp. & ,004 & ,005 &,- 065 & 851 & ,397 \\
\hline & Type of enterp. &,- 022 & 114 &,- 015 &,- 192 & 850 \\
\hline & Leader's exper. & ,002 & ,007 & 0,09 & 123 & ,904 \\
\hline
\end{tabular}

a. Dependent variable: Enterprise management performance

\begin{tabular}{|c|c|c|c|c|}
\hline Model & $\mathrm{R}$ & Squared R & $\begin{array}{c}\text { Adjusted } \\
\text { squared } \mathrm{R}\end{array}$ & $\begin{array}{c}\text { Estimation of } \\
\text { standard error }\end{array}$ \\
\hline 1 &, $492^{\mathrm{a}}$ &, 242 &, 194 &, 66581 \\
\hline
\end{tabular}

a. Predicators: (constant), self-esteem, the use, interaction,

Specialization, study level, employees, annual sales,

age of enterp., type of enterp., leader's exper.

Note for table 15: The regression is also significant at $\mathrm{R}^{2}=0.242$.However in this regression the only two explanatory significant variables are the self-esteem characteristic and the use of performance measures $(\mathrm{P}<0.05)$. Control variables and interaction term are not significant.

Table 16. Regression with interaction term for intolerance for ambiguity and the diversity performance measures

Coefficients $^{\mathrm{a}}$

\begin{tabular}{|c|c|c|c|c|c|c|}
\hline \multirow{2}{*}{\multicolumn{2}{|c|}{ Model }} & \multicolumn{2}{|c|}{$\begin{array}{c}\text { Non-standardized } \\
\text { coefficients }\end{array}$} & \multirow{2}{*}{$\begin{array}{c}\text { Standardized } \\
\text { coefficients }\end{array}$} & \multirow[b]{2}{*}{$\mathrm{t}$} & \multirow[b]{2}{*}{ Sig. } \\
\hline & & B & Std error & & & \\
\hline & (Constant) & 4,551 & ,253 & & 18,063 & ,000 \\
\hline & Intolerance & ,082 & ,072 & ,080 & 1,130 & ,262 \\
\hline & Diversity & 127 & ,047 & 205 & 2,748 & ,008 \\
\hline & Interaction & ,092 & ,017 & ,407 & 5,451 & ,000 \\
\hline & Specialization &,- 024 & ,087 &,- 019 &,- 262 & 795 \\
\hline & Study level &,- 094 & 106 &,- 064 &,- 885 & ,379 \\
\hline & Employees & $-7,8 \mathrm{E}-006$ & ,003 &,- 004 &,- 033 & 975 \\
\hline & Annual sales & ,007 & , 010 & ,065 & ,608 & ,546 \\
\hline & Age of enterp. & ,005 & ,005 & ,084 & 1,132 & 261 \\
\hline & Type of enterp. &,- 005 & 108 &,- 004 &,- 050 & 961 \\
\hline & Leader's exper. &,- 005 & ,007 &,- 015 &,- 197 & 845 \\
\hline
\end{tabular}

a. Dependent variable: Enterprise management performance

\begin{tabular}{|c|c|c|c|c|}
\hline Model & R & Squared R & $\begin{array}{c}\text { Adjusted } \\
\text { squared R }\end{array}$ & $\begin{array}{c}\text { Estimation of } \\
\text { standard error }\end{array}$ \\
\hline 1 &, $539^{\text {a }}$ &, 291 &, 245 &, 64417 \\
\hline
\end{tabular}

a. Predicators: (constant), intolerance, diversity, interaction,

specialization, study level, employees, annual sales,

age of enterp., type of enterp., leader's exper.

Note for table 16: The regression is significant at $R 2=0.291$. The variables diversity of performance measures and the interaction between diversity and intolerance of ambiguity are significant. No other predictor is significant at 0.05 . 
Table 17. Regression with interaction term for self-esteem and the diversity of performance measures

\begin{tabular}{|c|c|c|c|c|c|c|}
\hline \multicolumn{7}{|c|}{ Coefficients $^{\mathrm{a}}$} \\
\hline \multirow{2}{*}{\multicolumn{2}{|c|}{ Model }} & \multicolumn{2}{|c|}{$\begin{array}{l}\text { Non-standardized } \\
\text { coefficients }\end{array}$} & \multirow{2}{*}{$\begin{array}{c}\text { Standardized } \\
\text { coefficients }\end{array}$} & \multirow[b]{2}{*}{$\mathrm{t}$} & \multirow[b]{2}{*}{ Sig. } \\
\hline & & B & Std error & & & \\
\hline 1 & (Constant) & 4,488 & ,270 & & 16,711 & ,000 \\
\hline & Self-esteem & ,453 & 259 & 417 & 1,756 & 082 \\
\hline & Diversity & 174 & ,048 & ,280 & 3,693 & 000 \\
\hline & Interaction &,- 043 & ,062 & 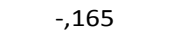 & -691 & 492 \\
\hline & Specialization &,- 036 & ,093 &,- 029 &,- 380 & ,706 \\
\hline & Study level &,- 171 & 110 &,- 115 & $-1,558$ & 122 \\
\hline & Employees &,- 002 & ,004 &,- 029 &,- 263 & 796 \\
\hline & Annual sales & ,006 & 011 & ,054 & ,477 & 636 \\
\hline & Age of enterp. & ,005 & ,005 & 081 & 1,031 & ,306 \\
\hline & Type of enterp. & ,037 & 114 &,- 025 &,- 320 & 751 \\
\hline & Leader's exper. &,- 002 & ,007 &,- 018 &,- 226 & 823 \\
\hline
\end{tabular}

a. Dependent variable: Enterprise management performance

\begin{tabular}{|c|c|c|c|c|}
\hline Model & $\mathrm{R}$ & Squared R & $\begin{array}{c}\text { Adjusted } \\
\text { squared R }\end{array}$ & $\begin{array}{c}\text { Estimation of } \\
\text { standard error }\end{array}$ \\
\hline 1 &, $468^{\mathrm{a}}$ &, 219 &, 169 &, 67584 \\
\hline
\end{tabular}
a. Predicators: (constant), self-esteem, diversity, interaction,
specialization, study level, employees, annual sales,
age of enterp., type of enterp., leader's exper.

Note for table 17: The regression is significant at $R^{2}=0.219$. The only explanatory variable in this case is the diversity of performance measures $(\mathrm{P}<0.05)$

Table 18. Regression with interaction term for the locus control and the diversity performance measures

Coefficients ${ }^{\mathrm{a}}$

\begin{tabular}{|c|c|c|c|c|c|c|}
\hline & & \multicolumn{2}{|c|}{$\begin{array}{l}\text { Non-standardized } \\
\text { coefficients }\end{array}$} & \multirow{2}{*}{$\begin{array}{c}\text { Standardized } \\
\text { coefficients } \\
\text { Beta }\end{array}$} & \multirow[b]{2}{*}{$\mathrm{t}$} & \multirow[b]{2}{*}{ Sig. } \\
\hline \multicolumn{2}{|c|}{ Model } & $\mathrm{B}$ & Std error & & & \\
\hline & (Constant) & 4,574 & ,255 & & 17,994 & ,000 \\
\hline & Locus control & 184 & 193 & 192 & ,955 & ,343 \\
\hline & Diversity & ,128 & ,047 & 206 & 2,758 & ,008 \\
\hline & Interaction & ,049 & ,045 & ,214 & 1,073 & 286 \\
\hline & Specialization &,- 024 & ,087 &,- 019 &,- 263 & 795 \\
\hline & Study level &,- 102 & 106 &,- 069 &,- 969 & ,336 \\
\hline & Employees &,- 002 & ,003 &,- 022 &,- 211 & ,835 \\
\hline & Annual sales & ,008 & ,010 & ,083 & ,772 & 443 \\
\hline & Age of enterp. & ,005 & ,005 & ,080 & 1,074 & 286 \\
\hline & Type of enterp. & ,015 & 110 & ,010 & 130 & 898 \\
\hline & Leader's exper. &,- 003 & ,007 &,- 022 &,- 287 & 776 \\
\hline
\end{tabular}

a. Dependent variable: Enterprise management performance

\begin{tabular}{|c|c|c|c|c|}
\hline Model & $\mathrm{R}$ & Squared R & $\begin{array}{c}\text { Adjusted } \\
\text { squared } \mathrm{R}\end{array}$ & $\begin{array}{c}\text { Estimation of } \\
\text { standard error }\end{array}$ \\
\hline 1 &, $538^{\mathrm{a}}$ &, 289 &, 243 &, 64491 \\
\hline
\end{tabular}

a. Predicators: (constant), locus control, diversity, interaction, specialization, study level, employees, annual sales,

age of enterp., type of enterp., leader's exper.

Note for table 18: The regression is also significant at $R^{2}=0.289$. The locus control and the diversity of PM are significant $(\mathrm{P}<0.005)$. 